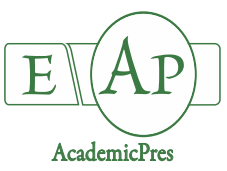

Ratnasingam J et al. (2020)

Notulae Botanicae Horti Agrobotanici Cluj-Napoca 48(4):1789-1801

DOI: $10.15835 / 48412167$

Review Article

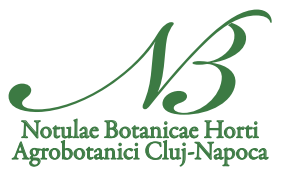

\title{
Plantation forestry in Malaysia: an evaluation of its successes and failures since the 1970
}

\author{
Jegatheswaran RATNASINGAM ${ }^{1 *}$, Hazirah A. LATIB ${ }^{1}$, \\ Neelakandan PARAMJOTHY², Lim C. LIAT ${ }^{1}$, \\ Mathivanan NADARAJAH ${ }^{2}$, Florin IORAS ${ }^{3}$
}

\author{
${ }^{1}$ University Putra Malaysia, Faculty of Forestry \& Environment, 43400 UPM, Serdang, Selangor, Malaysia; \\ jegaratnasingam@yahoo.com (*correspondingauthor); hazirahl@forr.upm.edu.my; choonliat@gmail.com \\ ${ }^{2}$ Forestry Consultants Inc., 16A-Lot 1, Persiaran Pegaga, Shah Alam 40000, Selangor, Malaysia; neela_p@forestconsultants.com.my; \\ mathi_n@forestconsultants.com.my \\ ${ }^{3}$ Buckinghamshire New University, Queen Alexandra Road, High Wycombe, HP11 2JZ Buckinghamshire, \\ England; florin.ioras@bucks.ac.uk
}

\begin{abstract}
With reducing supply of logs from the sustainably managed natural forest to meet the processing demand of the large wood products industry in Malaysia, plantation forestry has been gaining importance since the early 1970s. Despite the government's efforts through the provision of financial support and incentives, investments in plantation forestry has been slow. The promising start of the large-scale forest plantation programs in the early 1970 s, followed by the 1980 s and then the latest program in early 2000 , appear to have been a mixed bag of failures and limited success. The rather below-par performance of the forest plantations has been attributed to several factors, such as insufficient good planting stock, poor species-site matching, poor soil quality, pest and diseases and the overall poor silvicultural and management regime laid out for forest plantations. Further, plantation forestry appears to be dominated by larger companies, while small and medium companies, have limited financial resources to overcome the prevailing challenges faced. Despite the poor performance until to date, the adoption of intensive research based silvicultural and management regime for the plantation forests, which are maturing in the next years, will hopefully produce better results and serve as the sunrise for plantation forestry in Malaysia.
\end{abstract}

Keywords: forest plantation; economic viability; Malaysia; pest and disease; planting stock; soil quality

\section{Introduction}

The establishment of large-scale forest plantations globally did not begin until the 1960s, when worldwide deforestation had taken place at an alarming rate to facilitate agriculture activities, urbanization and other land use purposes (Szulecka et al., 2014). Plantation forests were established to satisfy the increasing global demand for timber products (FAO, 2016), and on recognizing the fact that these plantations have the potential to supply the worlds entire wood needs, its establishment continued to expand (Fenning and 
Gershenzon, 2002; Siry et al., 2005). Being well managed, forest plantations usually produce better quality wood, and have very high growth rates and short rotation lengths, and embrace tree improvement technology (Campinhos, 1999). Although, forest plantations are regarded as threats to biodiversity due to their monoculture status, the economic benefits offered often overrides this concern (Ratnasingam, 2019). With the globalization of the forest industries, forest plantation areas continue to increase and there is a shift of industrial plantations to the southern hemisphere (Korhonen et al., 2014), which inevitably reduces the pressure on primary forest, modified natural forest (FAO, 2016).

In the year 2000, forest plantations accounted for $5 \%$ of the global forest cover but produced $35 \%$ of global roundwood production (FAO, 2010; 2016). Hence, it is apparent that if the available forest plantations were to be well managed it could produce two thirds of global roundwood production (Christie, 2008). According to the Global Forest Assessment (FAO, 2020), the global forest plantation area had reached 294 million ha, with an average annual increment of $1.85 \%$, since 1990 . The higher average annual increment has been recorded in North and Central America (2.51\%), South America (2.38\%) and Asia (2.27\%) (FAO, 2020). Despite such impressive establishment rates, it is estimated that only half the plantations in Asia, Africa and Central America, are used for industrial wood production, while the remaining serve other purposes such as, watershed protection, fuelwood and desertification protection (FAO, 2020).

Forest plantations in the southern hemisphere are increasing in size and are playing an increasingly important role in supplying global timber markets (Sedjo, 1999). This is mostly due to faster growth rates that can range from 30 to $40 \mathrm{~m} 3$ per hectare per year compared to $10-15 \mathrm{~m} 3$ per hectare per year in the northern hemisphere (Siry et al., 2005). Forest plantations have expanded most rapidly in countries with densely populated rural areas that experience rural to urban migration, large tract of pasture lands, and have government policies that promote afforestation. In this context, forest plantations in South America is expected to expand rapidly in years to come, from 10.7 million ha at the turn of the century, to 26.7 million ha in 2050 (Daigneault et al., 2008). Other, countries in the southern hemisphere with sizeable forest plantations are South Africa, Australia, and New Zealand with 1.3 million ha, 1.0 million ha, and 1.5 million ha of forest plantations, respectively (FAO, 2020). It is expected that by 2050 , almost $75 \%$ of all wood supply in this region will come from forest plantations, which underlines the importance of industrial forest plantations.

\section{History of Forest Plantations in Malaysia}

Forest plantations on small trial plots, started as early as 1920's in Peninsular Malaysia, mainly for research purposes or due to the availability of seedlings from nursery trials (Selvaraj and Muhammad, 1980). Further, earnest efforts to establish forest plantations started in the 1950's after World War II, with the intention of afforesting and reclaiming lands degraded due to mining and human resettlement after the war (Johari and Chin, 1986). However, the first large-scale commercial forest plantation emerged with the proposed setting up of integrated pulp and paper mill in Peninsular Malaysia in 1967 (Freezailah and Fielding, 1971). Funded through a loan from the Asian Development Bank, the five-year pilot plantation for fastgrowing tropical Pine and Araucaria species was undertaken primarily for their long fibre pulp and ability to thrive on poor soils. Based on the promising growth rates recorded in these pilot plantations, large-scale plantations followed in 1974. Unfortunately, planting efforts fizzled out after a few years because the envisaged pulp mill construction in Peninsular Malaysia did not take-off and further the species planted at low altitudes did not regenerate under the local climatic conditions (Johari and Chin, 1986).

However, interests in the re-establishment of forest plantations were rekindled in 1979, to serve a twopronged strategy, as suggested by the Forest Department of Peninsular Malaysia to: (1) regulate and reduce annual log supply and (2) establish large-scale forest plantations, with the intention of protecting natural forests and to create a sustainable timber source supplying the industry. The need for an alternative multi-purpose wood resources supply to supplement the reducing supply from the natural forests was realized sooner than 
later. Hence, the Compensatory Forest Plantation Program (CFPP) was initiated in the 4th Malaysia Plan (1981-1985) to establish 188,000 ha with the objective of supplementing and complementing log supply from natural forests. Initially, species such as Acacia mangium, Paraserianthes falcataria and Gmelina arborea were the main species planted in Peninsular Malaysia, but due to the poor performance and site-specific nature of the latter two species, other species were also selected for planting. These included the native species Shorea leprosula, Dryobalanops aromatica, Hopea odorata, Dyera costulata and Endospermum malaccense, and exotic species such as, Khaya ivorensis, Hevea brasiliensis and Acacia hybrids. The state governments of Sarawak and Sabah in East Malaysia had similar programs aiming to generate a continuous supply of timber through forest plantations (Figure 1).

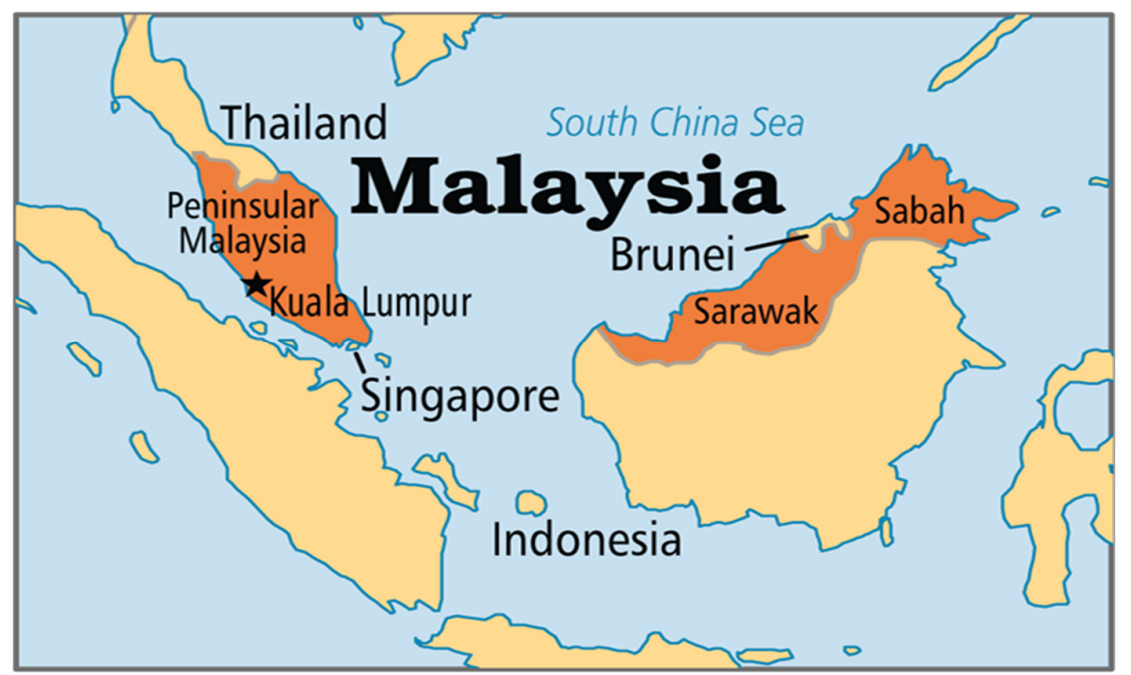

Figure 1. Peninsular Malaysia, Sarawak and Sabah

With few disease problems encountered in these forest plantations in the initial stages, such ventures were seen promising and promoted aggressively. However, with time, disease problems started to emerge. Heart rot disease in Acacia mangium was first discovered in Sabah (Gibson, 1981) and in the 1980s became widespread in plantations, affecting timber quality and yield (Lee, 2000). A decade later, the emergence of red root rot (associated with Ganoderma philippii) caused high mortality to mature Acacia mangium plantations in Peninsular Malaysia (Ito, 1999). Plantations between 10 and 14 years old reported more than $40 \%$ mortality in severely infected areas (Lee, 2003). Against this background, the Compensatory Forest Plantation Program failed to live up to its expectations, resulting in disbanded planting activities, as well as severe economic losses. This has been a painful experience for the Malaysian forest plantation initiative.

Against the dwindling supply of logs from the natural forests, from 49 million $\mathrm{m}^{3}$ of harvest in 1990 to 18 million $\mathrm{m}^{3}$ in 2019 (MTIB, 2019), there was an urgent need to address this shortage of raw material supply, which will affect the competitiveness of the USD 5.0 billion wood products industry in the country. In line with the National Timber Industry Plan (NATIP) launched in 2009, the establishment of forest plantations was deemed necessary if the anticipated shortage in raw materials supply is to be averted. Unfortunately, with limited interests from the private sector towards forest plantation establishments, as well as the previous unsuccessful ventures, the Malaysian Government launched another large-scale commercial forest plantation development phase with a new paradigm. Under this program, the Ministry of Plantation Industries and Commodities allocated USD 250 million to be administered by the Malaysian Timber Industry Board (MTIB) over 15 years to develop 375,000 ha of forest plantations (25,000 ha per year) in Peninsular Malaysia by the year 2020. From several promising species, eight were selected namely rubberwood (Timber Latex Clone or TLC), Acacia spp. (A. mangium and A. auriculiformis), Teak (Tectona grandis), Sentang (Azadirachta excelsa), Khaya spp. (K. ivorensis and K. senegalensis), Kelampayan/Laran (Neolamarckia cadamba), 
Paraserianthes falcataria, and Binuang (Octomeles sumatrana). To implement the program, a Special Purpose Vehicle (SPV) named Forest Plantation Development Sdn. Bhd. (FPDSB) was set-up with the following main functions: (1) promote the establishment of forest plantations for future timber supply, (2) manage the disbursement of soft loans, carry out auditing process of the plantations and provision of technical support, (3) create a proper trading centre for timbers produced by man-made forests. Once successfully implemented, every 25,000 ha of forest plantation established, is expected to produce 5 million $\mathrm{m}^{3}$ of timber $\left(200 \mathrm{~m}^{3}\right.$ per ha) (MTIB, 2019). To entice private sector interests and participation, the government provided with fiscal incentives such as soft loans payable after 15 years and investment tax allowance.

Even with such encouragements, the interests shown by the private sector towards the program was lukewarm, and the government decided to increase the allotted soft loans where disbursements per ha for rubberwood increased from USD,2000 to USD 2,500, and from USD 1,500 to USD 2,000 for forest tree species, the area for planting was reduced to 130,000 ha from the originally planned 375,000 ha. One of the main challenges identified has been the lack of land area for large-scale forest plantation establishment in Peninsular Malaysia, while in Sabah and Sarawak, such initiatives appear to have more takers especially among the large forest concession holders (MTIB, 2019).

At the end of 2019, a total of 116,000 ha of forest plantations have been established in Peninsular Malaysia, of which rubberwood and other forest species comprise 80,700 and 35,300 ha respectively (FPDSB, 2019). On the other hand, Sabah, which is a state in East Malaysia, had established 357,000 ha largely with Acacia mangium, Paraserianthes falcataria, Eucalyptus grandis, E. deglupta, E. pellita and N. cadamba, although the targeted planting area was 500,000 ha. Sarawak, being the state in East Malaysia had also pursued this initiative aggressively, and a total of 451,000 ha has been planted in with similar tree species, despite 1 million ha being ear marked initially for forest plantation establishments (MTIB, 2019).

Despite the fact, that almost 1 million ha of forest plantations has been established in Malaysia by the end 2019, the question of sustainable industrial wood supply to cater for the needs of the large wood products sector in the country remains unanswered and has created much anxiety among the large number of wood products manufacturers in the country. Therefore, the main objective of this paper is to provide a comprehensive review of the status of forest plantation establishment in the country and the main challenges faced. It also aims to highlight the fact that a large down-stream wood processing sector must be well supported by a sustainable supply of wood resources from plantation forest as well as natural forest, to ensure the viability of the down-stream wood-products industry.

\section{Production Potential and Challenges of Forest Plantations in Malaysia}

Table 1 shows the current production volume of saw logs from plantation forests in Malaysia, and it is apparent that based on the present production rate and its utilization, the demand for industrial wood supply from the large wood products industry in the country may not be fully met. Almost $60 \%$ of the production volume from Sabah and Sarawak are exported to East Asia and Indonesia, and therefore, the actual volume of wood supply available for domestic consumption from the plantation forests, is indeed much smaller than anticipated (MTIB, 2019). It has been noted that much of this exported plantation wood supply are used for production of chips for biomass energy as well as for pulp and paper production. Therefore, the capacity of these forest plantations in Malaysia to ease the insufficient wood supply in the domestic market is limited. In this context, the ability of forest plantations to ease the pressure on log production from the natural forests remains limited. 
Table 1. Production of logs from forest plantations in Malaysia

\begin{tabular}{|c|c|c|c|c|}
\hline Region & $\begin{array}{l}\text { Wood output } \\
\text { volume per year } \\
\text { from plantation } \\
\quad \text { forest }\left(\mathrm{m}^{3}\right)\end{array}$ & $\begin{array}{l}\text { Total harvest area } \\
\text { (ha) per year }\end{array}$ & $\begin{array}{l}\text { Specie composition } \\
\text { (rubber: other species, } \\
\text { including Acacia, } \\
\text { Eucalyptus) as total of } \\
\text { planted area }\end{array}$ & $\begin{array}{c}\text { Ratio of Export: } \\
\text { Domestic } \\
\text { Consumption }\end{array}$ \\
\hline Peninsular Malaysia & 1.5 million & 15,000 & $85: 15$ & $18: 82$ \\
\hline Sarawak & 1.7 million & 8,500 & $40: 60$ & $70: 30$ \\
\hline Sabah & 600,000 & 3,000 & $45: 55$ & $65: 35$ \\
\hline
\end{tabular}

Data Source: STIDC, STA, FDPM

One of the main challenges faced in forest plantation establishments in Malaysia is the land used for such purposes. In Peninsular Malaysia, forest plantations must be developed on state or alienated (privatized) land with prior approval from respective state forestry departments, and not on Permanent Reserved Forests (PRFs), which are gazetted for conservation and water catchment. In Sabah, approved areas are in zones for Industrial Tree Plantation (ITP) under the Sustainable Forest Management License Agreement (SFMLA) while in Sarawak, areas with a License for Planted Forest (LPF) can be developed. Such practices have been put in place to ensure that issues related to land tenure may not arise in the future, affecting the viability of the established forest plantations. Further, this is particularly relevant as most of these forest plantations would need to comply with forest management schemes under the Malaysian Timber Certification Scheme (MTCS), which is recognized as a scheme under the to the Pan-European Forest Certification (PEFC) scheme. This compliance is crucial if the planation wood supply is to find application in main stream wood products manufacturing such as furniture, mouldings, joinery, etc., which make up almost $50 \%$ of the value-added wood products exports from the country.

In most instances, however, the land for forest plantation establishments in the country is under difficult terrains and therefore, planting activities may be constrained and incur relatively high cost, which in turn explains the below-target annual planting rate experienced until to date. This also explains the lack of participation by smaller players in forest plantation establishments in Malaysia as many of them cannot afford to incur the high capital input cost (Ratnasingam, 2019). The other challenges faced in forest plantations establishment in Malaysia, are the quality of soils, management of pests and diseases, and the sufficient supply of good planting material, which to a large extent continue to constraint the future sustainability of forest plantations in the country.

\section{Land and Soil Quality for Forest Plantations}

Soil and nutrient management in plantation forests in Malaysia is a necessity, as most of these plantations have been established on poor quality soil with poor fertility (Koslowski, 1970). Unlike rubber and oil palm plantations, fertilizer is not a major input in plantation forests because the long gestation period requires minimal planting costs. Fertilizing is carried out only to boost initial tree growth, and accounts for only $1 \%$ of the establishment cost (Ahmad Zuhaidi et al., 2007). In the early days, forest plantations in Malaysia were established through afforestation in areas left abandoned after agriculture or mining activities, and the soil was relatively of low fertility. Over the years, reforestation activities took place in clear-felled logging tracts where wood debris was burnt after high-value logs were extracted. Roots were left intact to decompose gradually. With the current awareness of the need to protect the environment, the practice of zero-burning and the utilization of degraded sites, even tin tailings, and BRIS soils, for forest plantation establishment is on the rise (Ahmad Zuhaidi et al., 2007). Nevertheless, the fact that forest plantations occupy land of poor fertility is an important management factor that must be addressed to ensure successful forest plantations. 
When the first systematic forest plantation of exotic species was established in Peninsular Malaysia, little was known about species adaptation to sites and survival under local conditions. Few problems were encountered with early plantation trials, but subsequent plantings were unsatisfactory. Growth rates were not as expected, and in many instances, early mortality of the plantings was recorded. Further, in other parts of the country, the trees showed symptoms of ill health (Freezailah and Fielding, 1971). There were also cases where young, healthy trees developed symptoms of ill health as they aged, usually after 10 years of growth.

Among the reasons for such poor performances were nutritional disorders, poor site adaptation and to a lesser extent, diseases. According to Koslowski (1970), the ill health phenomenon discovered in Pinus plantations in Malaysia was attributed to nutrient deficiencies compounded in some cases by competing weeds. Phosphorus (P) deficiency was the dominant contributor while insufficient nitrogen $(\mathrm{N})$ supply also limited tree growth.

Generally, Malaysian soils have low available P due to high P fixation. In the compensatory plantation, a nutrient re-translocation study carried out on a two-year-old stand of $A$. mangium and $K$. ivorensis, found a high re-translocation of $\mathrm{P}$ (Wan Rasidah et al., 1998). P was returned to the tree even at the leaf yellowing stage, while $\mathrm{N}$ and potassium $(\mathrm{K})$ were also re-translocated, but at a much lower percentage. Bon and Harwood (2016) reported that fertilizer application increased growth of Acacia hybrid in the first three years of establishment, but by the fourth-year wood volumes were similar for fertilized and unfertilized trees at $100 \mathrm{~m}^{3}$ per ha. Notably, fertilizer input led to poorer stem form and early branching, necessitating pruning activities.

\section{Pest and Disease Management in Forest Plantations}

Pest and disease incidences are inevitable in forest plantations, as such monocultures are generally susceptible to diseases. Therefore, it is imperative that a proper management plan for pest and disease control be put in place. Cases of forest plantations failures due to serious pest and disease attacks especially during the early phase are well documented (Wingfield, 1999). According to Lee (2014), very few disease problems were experienced with $A$. mangium when it was first introduced, and hence encouraging it to be promoted as easy to grow plantation tree species. However, over time, problems started to emerge. Heart rot disease in $A$. mangium was first discovered in Sabah (Gibson, 1981) and in the 1980s became widespread in plantations, affecting timber quality and yield (Lee et al., 1988; Hashim et al., 1990; Zakaria et al., 1994). A decade later, the emergence of red root rot (due to the fungus Ganoderma philippii) caused high mortality to mature $A$. mangium plantations in Peninsular Malaysia (Ito, 1999; Lee, 2003). Plantations between 10 and 14 years old reported more than $40 \%$ mortality in severely infected areas (Lee, 2003).

At the nursery stage, a correlation between unhealthy seedlings and needle blight disease susceptibility was found for various species of Pinus (Koslowski, 1970). The disease was caused by the fungus Nigrospora followed by four other secondary fungal invaders. Affected seedlings were distinguished by browning and death of the lower needles at the early stage and terminal bud attack at a later stage. Nursery trial treatment results were unexpected, as affected seedlings showed little response to fungicide. It was later found that periodic fertilizer applications to an extent prevented the disease (Freezailah and Low, 1986).

The most recently reported threat to Acacia spp. is vascular wilt disease (caused by the Ceratocystis fungus), which was first found in 2005 in Indonesia, and now affects significant areas of plantation in Sabah and Sarawak, and parts of plantations in Johor and Pahang of Peninsular Malaysia (Lee, 2017). The problem was so severe that many young plantations were badly affected with very high mortality rates, forcing plantation forest companies to abandon A. mangium in favour of other fast-growing tree species such as Eucalyptus pellita and E. deglupta (Mohd Farid et al., 2017). This is particularly the case in Sabah and Sarawak, where sizable area of land under Acacia mangium had be discarded and felled to be replaced with other tree species. Unfortunately, as of to date, no effective method is available to control this disease, and it remains a challenge to forest plantation owners. 
Although, diseases affecting other forest plantation species have not been widely reported, and reports on this subject is limited, the challenges posed by pests and diseases in forest plantations in Malaysia remains a major concern. This is a work in progress for the new tree species such as E. pellita, E. deglupta and others, as forest plantation owners grapple with forest plantation management practices to avoid such problems.

\section{Supply of Quality Planting Stock}

It has been acknowledged that good selection of tree species and sites, high-quality genetic material and improved techniques are key ingredients of successful forest plantation projects (Nambiar et al., 2015). Potential investors in forest plantations prefer to have plant material of high quality (even if paying more) and suitable species for the sites to ensure high performance. In this context, research and development (R\&D) activities are essential to systematize technical knowledge on selection of sites, species and provenances, methods of propagation and maintenance of planted areas (Ratnasingam, 2019). In essence, the success of reforestation projects should be underpinned by good science, as well as the keenness of the scientists to pursue it.

In Malaysia, a large proportion of the planting stock used in forest plantations come from nurseries that specialize in its production (MTIB, 2019). Trees grown from seeds are known as seedlings, but in Malaysia, the availability of seedlings for forest plantations establishment is somewhat limited, except for some of the more established species such as Acacia mangium and Paraseriathes falcataria (MTIB, 2019). Therefore, it is no surprise that increasingly vegetative propagation techniques, especially tissue culture, are used to produce large quantities of planting stocks. Since planting stocks for forest plantations is a rootstock from which a tree is expected to grow, it is imperative that the planting material produced is of high quality, to ensure successful growth performance of the trees in the field. It has been reported that the available supply of planting stock is only sufficient to support the establishment of approximately $73 \%$ of the targeted planting area in the country, clearly underlining the need to boost planting stock production capacity (MTIB 2019). Perhaps, this is a role for organizations such as the Forest Research Institute of Malaysia (FRIM) and the Faculty of Forestry \& Environment at Universiti Putra Malaysia (UPM), which have been the leading research organizations for the forestry and forest industries in the country since independence. This would also ensure that the quality of the planting stock for future forest plantation establishments is assured.

Nevertheless, it must be emphasized that the constraints imposed by the weights of investments and commitments made during nursery development, may pose another huge challenge to small forest plantation owners in the country. Typically, large forest companies and governments managing forests tend to establish their own nurseries, while small-scale forestry operators tend to purchase the planting stock from independently owned nurseries with specialized production of planting stock for sale only (Nambiar et al., 2015). According to FAO (2020), the quality of the planting stock and its sufficient supply have a profound effect on the success of forest plantations, and perhaps, it is one area that warrant even greater research and development $(R \& D)$ inputs in the country.

\section{Research and Development Needs in Forest Plantations}

Despite the credible efforts by the Forest Research Institute of Malaysia (FRIM), the Forest Departments of Peninsular Malaysia, Sabah, and Sarawak, to carry out planting trials, to assess the species sitesuitability, silvicultural and management regime requirements for each of the recommended forest plantation tree species since the 1980s, forest plantation establishments in Malaysia remains a mixed bag of both successes and failures. It is apparent that, the main motivation of plantation forests establishments in Malaysia is often fuelled by the availability of soft-loans and subsidies from the government, and the participants are usually large 
forest concession holders, who would venture into forest plantations to appease the government in order to retain their logging license (Ahmad Zuhaidi, 2012). Further, the prevailing soil quality and agroecological factors of the logged over land available for forest plantations often resulted in variable growth performance of the trees on the site, often yielding poor results than anticipated, which may also turn out to be not attractive to smaller companies due to the risk factors involved. Unfortunately, the provision of soft-loans and incentives appears to be more attractive to larger companies, which in turn have kept out smaller companies from venturing into this business, which is contrary to what is seen in Vietnam (Ratnasingam, 2019).

The successful community forestry practices in Vietnam and the development of an intricate network of supply chain for the wood resource, has been hailed as one of the main contributory factors for the booming wood products industry in Vietnam, especially with regard to Acacia wood-based products. It is therefore, not a surprise that the total forest plantation area in Vietnam has breached 3.5 million ha in 2018 and it continues to grow, in support of the growing demand for Acacia wood supply (Ratnasingam, 2020).

For many opponents of plantation forests in Malaysia, the cultivation of exotic species is more troublesome than venturing into the more established species, such as rubber (Hevea brasiliensis) and other natural forest tree species. Despite being the predominant wood material for the wood products industry in the country, its stature as a premium raw material for value-added wood products is somewhat limited and is often regarded a "cheap wood' in comparison to the other wood species from the natural forests (Ratnasingam, 2020). Unfortunately, for many native species, including Shoreaspp. and Dipterocarpus spp. the irregular production of recalcitrant seeds thwarts their effective use in plantation forestry.

However, recent advances in plant propagation using stem cuttings mean that this obstacle may be overcome for such species. Considering the high initial capital involved in plantation forestry establishment, clonal forestry (using genetically improved material) will increasingly play an important role in the success of such investments. The economic advantage is that clonal plantation yields a uniform product tailored to the requirements of the wood processing industry. The selected clone usually has fast growth rate and high wood density and is more profitable compared to seed-based planting. Nevertheless, it must be cautioned that the clones must be properly tested because there may be differences in growth performance in variable environments. Mediocre or untested clones should be avoided. Further, testing should be conducted on major site types in the targeted planting environment, to eliminate any surprising growth performances (Ratnasingam, 2019). This is of particular interest, as there are indications that insufficient supply of quality planting stock is a prevailing challenge faced in forest plantation establishments.

In this respect, one of the forest plantation species that is fast gaining importance in Malaysia is the Revotropix Paulownia, a tree species that shows a tremendous growth rate. Since being introduced to the country over the last decade, almost 16,000 ha has been planted in Peninsular Malaysia, up to date. It planting stock produced through tissue culture appears to be of consistent quality with expected growth performance. Although its wood quality is comparable to that of Chinese Poplar, the acceptance of this specie as a forest plantation tree of choice is very much in its early days, and further research and development work must be pursued intensively to confirm its growth performance and wood quality (Ratnasingam, 2019). The other forest plantation tree species that appears promising are Eucalyptus pellita and Acacia hybrid, which are also seeing growing interests in its cultivation throughout the country.

Therefore, continuous long-term research program is a pre-requisite to support any effective forest plantation program, even if a good initial choice of planting species has been made. Research needs to be conducted locally to fill knowledge gaps and solve problems arising in local conditions. This is often glaring in Sarawak and Sabah, where forest plantations have produced varied results and economic returns, clearly indicating why small plantation owners cannot sustain in such an environment (Korhonen et al., 2014). Further, as these plantations are generally owned by large companies, the space for small and medium companies in plantations forests is curtailed to a large extent. Research results should also be made readily available to potential forest investors in the form of practical and accessible management recommendations if the interests in forest plantations is to be expanded further in the future. Perhaps, long-term research 
cooperation between private forest plantation owners, research organizations, and universities of mutual benefit should be encouraged (Ratnasingam, 2020).

\section{The Viability of Plantation Forestry in Malaysia}

The wood products industries in the country have long recognized that existing natural forests in the country cannot continue to meet their raw material requirements, and investments in plantation programs are expected to play a significant role in the coming years. The targeted value of wood products exports of USD 13 billion by 2020 as stated in the National Timber Industry Plan (NATIP) of 2009, had to be revised downwards to USD 6 billion, due to the severity of the wood resources shortage in the country (MTIB, 2019). In lieu of the shortage, wood importation from North America, Europe, and New Zealand have been on the rise since 2016.

Since 2000, plantation companies in Malaysia have been promoted as viable investments in tree planting schemes to potential investors, at low investment rates with expectations of high returns after as few as 20 years. Such tree plantations could certainly contribute to the supply of timber and could help to increase the total forest cover in the country. However, for guaranteed success, tree investment programs must be consistent with silvicultural and market needs, or risk failing to achieve their objectives. Market research and a sound business plan is crucial to ensure the return on investment is acceptable. Experiences from rubber cultivation by small holders clearly emphasizes the need for sound economic return, or else such ventures will run the risks of requiring assistance from the government in the form of subsidies in order to remain viable (Ratnasingam, 2019).

Since the first large-scale forest plantation scheme known as the Compensatory Forest Plantation Project (CFPP) was launched in 1982, following projections that Peninsular Malaysia would experience acute timber shortages for domestic use by the year 2000 (Chong, 1979), the contribution of forest plantations towards wood supply has been limited, as its trend has been chequered by more failures than successes. Table 2 provides the status of forest plantations in Malaysia, and the main species planted.

Table 2. Forest plantation area in Malaysia and main species planted

\begin{tabular}{|l|c|c|c|}
\hline \multirow{2}{*}{ Species planted } & \multicolumn{2}{c|}{ Total planted area (ha) } \\
\cline { 2 - 4 } & Peninsular Malaysia & Sarawak & Sabah \\
\hline Rubber (Hevea sp.) & $1,120,000$ & 193,000 & 190,000 \\
\hline Acacia mangium & 4,500 & 283,000 & 50,000 \\
\hline Acacia hybrid & 2,000 & 14,000 & 4,500 \\
\hline Paraserianthes falcataria & n. a & 64,500 & 14,200 \\
\hline Neolamarckia cadamba & n. a & 52,000 & 7,000 \\
\hline Eucalyptus pellita & 5,700 & 8,000 & 19,000 \\
\hline Eucalyptus grandis & n. a & 12,000 & 19,000 \\
\hline Eucalyptus deglupta & n. a & 3,000 & 2,500 \\
\hline Others & 17,000 & 4,000 & 1,200 \\
\hline
\end{tabular}

Data Source: STIDC, STA, FDPM

Although the Ministry of Plantation Industries and Commodities Malaysia had projected log supply from forest plantations to reach 16.7 million $\mathrm{m}^{3}$ per annum from 2018 onwards, unfortunately, this has not been the case (MPIC, 2009; MTIB, 2019). Although, forest plantations are generally more efficient in producing commercial timber than natural forests, with annual increments of $20-25 \mathrm{~m}^{3}$ per year, the poor silvicultural practices and management of such forest plantations in Malaysia has resulted in poor yield (Dai $e t$ al., 2016). Factors such as poor planting site quality, pest, and diseases, as well as the supply of quality planting material remain the main challenges faced. 
It must also be recognized that the economic viability of plantation forests is crucial to ensure it sustainability. In this context, the tree species planted, its wood quality and its market acceptance will determine its value-proposition and the overall financial viability of such ventures. If exports for pulp and paper or biomass energy industries predominate, it may be difficult to achieve the financial returns expected, as these are very competitive markets (Ratnasingam, 2019). On the other hand, its acceptance as raw material for value-added wood products manufacturing, will take a huge effort in marketing and promoting it, similar to what was done for rubberwood (Hevea brasiliensis) in the early 1980s by the Malaysian Timber Industry Board (MTIB) and the Forest Research Institute of Malaysia (FRIM).

The success of forest plantations in other countries such as New Zealand, Brazil and Chile, clearly suggest a need for a long-term vision and well-supported research and development (R\&D) to make such ventures an economic success. The need for an extensive research network between the private sector, government agencies and universities cannot be underplayed in Malaysia, as the research outcomes will lay the foundation for future plantation forestry success in the country. It is also clear that in the past, many of the recommended tree species for forest plantations have not been thoroughly researched, leading to poor performances and yield. These lost years, appear to have resulted in the acute shortage of wood supply, affecting wood products exports negatively. In a study by Ratnasingam and Lim (2019), it was shown that many sawmills, veneer and plywood mills as well as value-added wood products mills are operating below capacity due to shortage of wood raw materials, leading to low outputs and exports.

Nevertheless, forest plantations maturing in the next few years will be an important indicator of the success of plantation forestry in Malaysia and shall provide evidence if the lessons from the past have been put to good use. A review of the recommended species suggests that Hevea brasiliensis, Eucalyptus species, hybrids of Acacia are the most promising candidates with the lowest risk for short rotation plantation forestry in Malaysia (Nambiar et al., 2015; Ratnasingam 2020). These genera, with the exception, of the timber-latex clones of rubber, produce seeds that are easily stored for years without losing viability, thus making it easy to schedule nursery production. Against this background, it is hoped that the economic role of plantation forestry in Malaysia will be further enhanced in the very near future, and the plantation forestry sector would become a serious alternative wood resource supplier, as the country is already in a resource-deficit situation, being a net importer of wood resource (Ratnasingam, 2019).

\section{Conclusions}

1. With intensive efforts to reduce pressure on natural forest and ensure a continuous supply of wood for the domestic wood products industry, expanding plantation forestry in Malaysia is inevitable.

2. However, to guarantee success, plantation forestry establishments must be supported by research and development to lay down proper silvicultural and management regimes.

3. Investments in plantation forestry must not only focus on expanding the plantation area but must also undertake research activities to sustain good growth performance under local conditions and soil types.

\section{Authors' Contributions}

Conceptualization JR and HaL, Validation NP and CH, Validation FI, Writing JR and FI, Writingreview and editing FI and $\mathrm{MN}$

All authors read and approved the final manuscript. 
Ratnasingam J et al. (2020). Not Bot Horti Agrobo 48(4):1789-1801

\section{Acknowledgements}

The support of the Forest Department of Peninsular Malaysia, Forest Department of Sarawak and Forest Department of Sabah in providing the necessary statistics on forest plantations in much appreciated. The assistance of the Centre for Forest Plantations in Singapore is also acknowledged.

\section{Conflict of Interests}

The authors declare that there are no conflicts of interest related to this article.

\section{References}

Ahmad Zuhaidi Y, Hashim MN, Ahmad FS (2007). Commercial forest plantation programme in Malaysia: the future wood supply. In: Proceedings of the Conference on Forestry and Forest Products Research: Balancing Economic and Ecological Needs, Kuala Lumpur, Malaysia, pp 218-222.

Ahmad Zuhaidi Y (2012). Evaluating the growth performance of four-year-old Neolamarckia cadamba in Malaysia. The Planter 88(1038):617-623.

Bon P, Harwood C (2016). Effects of stock plant age and fertiliser application at planting on growth and form of clonal Acacia hybrid. Journal of Tropical Forest Science 28:182-189.

Campinhos E (1999). Sustainable plantations of high-yield shape Eucalyptus trees for production of fiber: the Aracruz case. New For 17:129-143. https://doi.org/10.1023/A:1006562225915

Chong PW (1979). The growing domestic demand for timber and its influence on forest management. Malayan Forester 42:376-399.

Christie S (2008). Energy, chemicals and carbon: future options for the Eucalyptus value chain. Southern Forests: A Journal of Forest Science 70(2):175-182. https://doi.org/10.2989/SOUTH.FOR.2008.70.2.13.541

Dai J, Welham C, Cao L, Cao F (2016). Sustainable production in subtropical hybrid poplar plantations. Journal of Tropical Forest Science 28:190-204.

Daigneault AJ, Sohngen B, Sedjo R (2008). Exchange rates and the competitiveness of the United States timber sector in a global economy. Forest Policy and Economics 10(3):108-116. https://doi.org/10.1016/ j. forpol.2007.07.001

Fenning TM, Gershenzon J (2002). Where will the wood come from? Plantation forests and the role of biotechnology. Trends Biotechnology 20(7):291-296. https://doi.org/10.1016/S0167-7799(02)01983-2

Food and Agricultural Organisation of the United Nations (2010). Global forest resources assessment 2010. main report. FAO forestry paper no. 163; Food and Agricultural Organisation of the United Nations, Rome, Italy. Retrieved 2018 August 29 from http://www. fao.org/docrep/013/i1757e/i1757e.pdf

Food and Agricultural Organisation of the United Nations (2016). Global forest resources assessment 2015. How are the world's forests changing? Second Edition, Food and Agricultural Organisation of the United Nations, Rome, Italy. Retrieved 2018 August 29 from http://www.fao.org/3/a-i4793e.pdf

Food and Agricultural Organisation of the United Nations (2020). Global forest resources assessment 2020. Main Report, Food and Agricultural Organization of the United Nations, Rome, Italy. Retrieved 2020 November 14 from https://doi.org/10.4060/ca9825en

FDPM (2018). Forest Plantation Development Sdn Bhd. 2018, 16 January. Minutes of Meeting: Physical Progress of Forest Plantation Development Programme (2). Ministry of Primary Industries and Commodities, Putrajaya, Malaysia

Freezailah CY, Fielding, JM (1971). The Development and results of the pilot plantation project and prospects for the future. FO: SF/MAL/12. Working Paper No.18. FAO, Rome.

Freezailah CY, Low CM (1986). Some preliminary observations on the attack and control of a fungal (Pestalotia sp.) disease on seedlings of Pinus caribeae. Malayan Forester 31:15-19.

Gibson IAS (1981). Seed source establishment and tree improvement - Sabah, Malaysia. FAO/UNDPMAL/78/009, Forest Mycology Consultant's Report No. 3. FAO, Rome. 
Hashim MN, Maziah Z, Sheikh Ali A (1990). The incidence of heart rot in Acacia mangium Willd. plantations: a preliminary observation. In: Proceedings of a Conference on Forestry and Forest Products Research, Kepong, Malaysia pp 54-59.

Ito S (1999). Annex 8: Incidence and severity of root disease at Acacia mangium plantations in the multi storied forest management project. Integrated Report on the Multi-Storied Forest Management Project in Malaysia (19911999). Forestry Department Peninsular Malaysia, Perak State Forestry Department, Japanese International Cooperation Agency, Kuala Lumpur.

Johari B, Chin TY (1986). Review of plantation experiences in Peninsular Malaysia. In: Proceedings of the Ninth Malaysian Forestry Conference, Kuching, Malaysia pp 213-242.

Korhonen J, Toppinen A, Cubbage F, Kuuluvainen J (2014). Factors driving investment in planted forests: a comparison between OECD and non-OECD countries. International Forestry Review 16(1):67-77. https:// doi.org/10.1505/146554814811031314

Koslowski TT (1970). Physiological implications in establishment and growth of quick-growing species in Malaysia. (Technical Report No. 2), FAO, Rome.

Lee SS, Teng SY, Lim MT, Razali AK (1988). Discoloration and heart rot of Acacia mangium Willd: some preliminary results. Journal of Tropical Forest Science 1:170-177.

Lee SS (2003). Pathology of tropical hardwood plantations in South East Asia. New Zealand Journal of Forestry Science 33(3):321-335.

Lee SS (2014). Lamenting the state of mycology and forest pathology in Malaysia. Journal of Tropical Forest Science 26(4):443-445.

Lee SS (2017). Ceratocystis wilt: a threat to Malaysian forest plantations. In: Prosiding Bengkel Penyakit Layu. Temerloh, Malaysia pp 3-6.

Ministry of Plantation Industries and Commodities (2009). NATIP: National Timber Industry Policy 2009-2020. MPIC, Putrajaya.

Malaysian Timber Industry Board (MTIB) (2019). Annual report of the Malaysian Wood Industry, Kuala Lumpur, Malaysia.

Mohd Farid A, Syazwan SA, Wan Muhammad Azrul WA, Patahayah M, Mohd Salleh S, Abriza MZ (2017). Penyakit layu disebabkan kulat Ceratocystis di ladang Acacia mangium di Malaysia dan ancamannya kepada pokok hutan dan pokok pertanian terpilih. In: Wan Rasidah K et al. (Eds). Penyakit Layu: Risiko dan Ancaman Terhadap Perladangan Acacia mangium di Malaysia. Prosiding Bengkel Penyakit Layu. 11-12 January 2017, Temerloh, Malaysia pp 21-24.

Nambiar EK, Harwood CE, Kien ND (2015). Acacia plantations in Vietnam: research and knowledge application to secure a sustainable future. Southern Forests 77(1):1-10. https://doi.org/10.2989/20702620.2014.999301

Ratnasingam J (2019). Status and challenges of plantation forestry in Malaysia: a cost-benefit analysis. Report for the Investment Unit of Malayan Banking Group Berhad, Kuala Lumpur, Malaysia.

Ratnasingam J, Lim CL (2019). Status of wood products manufacturing in Malaysia: An Evaluation of the Raw Material and Labour Input. IFRG Report No. 16-SP, Singapore.

Ratnasingam J (2020). Success and challenges of plantation forestry in Malaysia - lessons for the future. Report for the Centre for Resource Industries, PT Wirajaya Group, Singapore.

Sedjo RA (1999). The potential of high-yield plantation forestry for meeting timber needs. New For 17:339-360. https://doi.org/10. 1023/A:1006563420947

Selvaraj P, Muhammad AB (1980). A checklist of plantation trials in Peninsular Malaysia (Research Pamphlet No. 79), Forest Research Institute Malaysia, Kepong.

Siry JP, Cubbage FW, Ahmed MR (2005). Sustainable forest management: global trends and opportunities. Forest Policy Economics 7(4):551-561. https://doi.org/10.1016/j.forpol.2003.09.003

Szulecka J, Pretszch J, Secco L (2014). Paradigms in tropical forest plantations: a critical reflection on historical shifts in plantation approaches. International Forestry Review 16(2):128-143. https://doi.org/10.1505/ 146554814811724829

Wan Rasidah K, Van Cleemput O, Zaharah AR (1998). Nutrient re-translocations during the early growth of two exotic plantation species. In: Schulte A, Zuhiyat D (Eds). Soils of Tropical Forest Ecosystems: Characteristics, Ecology and Management. Springer-Verlag, Berlin pp 133-136.

Wingfield MJ (1999). Pathogens in Exotic Plantation Forestry. International Forestry Review 1(3):163-168. 
Zakaria I, Wan Razali WM, Hashim MN, Lee SS (1994). The incidence of heartrot in Acacia mangium plantations in Peninsular Malaysia. FRIM Research Pamphlet No. 114. Forest Research Institute Malaysia, Kepong.

OPEN ACCESS

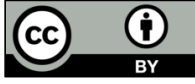

The journal offers free, immediate, and unrestricted access to peer-reviewed research and scholarly work. Users are allowed to read, download, copy, distribute, print, search, or link to the full texts of the articles, or use them for any other lawful purpose, without asking prior permission from the publisher or the author.

License - Articles published in Notulae Botanicae Horti Agrobotanici Cluj-Napoca are Open-Access, distributed under the terms and conditions of the Creative Commons Attribution (CC BY 4.0) License.

(c) Articles by the authors; UASVM, Cluj-Napoca, Romania. The journal allows the author(s) to hold the copyright/to retain publishing rights without restriction. 